\title{
Service Differentiation and Organization Performance: An Empirical Analysis of Deposit Taking Saccos in Nairobi City County, Kenya
}

\author{
Josephine Waithira Mbugua, Godfey Muigai Kinyua \\ School of Business, Kenyatta University, Nairobi, Kenya \\ Email address: \\ Josephine10207@gmail.com (J. W. Mbugua),jefkinyua@gmail.com (G. M. Kinyua) \\ To cite this article: \\ Josephine Waithira Mbugua, Godfey Muigai Kinyua. Service Differentiation and Organization Performance: An Empirical Analysis of \\ Deposit Taking Saccos in Nairobi City County, Kenya. Journal of Business and Economic Development. Vol. 5, No. 2, 2020 , pp. 64-72. \\ doi: $10.11648 /$ j.jbed.20200502.12
}

Received: February 25, 2020; Accepted: March 13, 2020; Published: April 10, 2020

\begin{abstract}
The Sacco sub sector occupies a strategic position in the socio-economic development of the country. Cost of doing business and reduced saving power of the Saccos customers have reduced the revenue and access to cheap deposits that they use to give as loans to their members making them re-think their competitive strategy in order to remain competitive and increase performance. This study sought to determine the effects of service differentiation strategy on performance of deposit taking Saccos in Nairobi City County, Kenya. Descriptive research design was employed with respondents drawn from 123 deposit taking Saccos that were obtained using stratified random sampling technique. Data analysis was done by the use of descriptive statistics and simple linear regression statistics. The study found that staff provided consistent service to the members, gave commission incentives to the members who gave referrals, offered differentiated mobile platform financial services, gave unique service experience to the members, were prompt in handling customer's complaints and members were happy with the services. The study also found that Deposit Taking Saccos were not using members' feedback and quarterly surveys to improve service. The study found that Service differentiation had the following values $(\beta=0.348, p=0.005<0.05)$. The study concluded that service differentiation had positive and significant effect on performance of deposit taking Saccos. The study recommends that Sacco management should come up with standard procedures and guidelines that will be used to reinforce the effective implementation of feedback received from customers to spearhead service improvement.
\end{abstract}

Keywords: Service, Differentiation, Performance, Saccos

\section{Introduction}

Change of strategy has brought about performance improvement in businesses. The change has globally been necessitated by the pressure created in businesses due to technological improvement, competition and more demanding customers [35]. Reforms in Africa within the financial sector have brought development which has on the other hand resulted to performance improvement across the industry [33]. The growth in the financial industry within Kenya has increased competition and it demands that the Sacco sector within the country must rethink their strategies in order to sustain good performance and avoid close down. The Sacco sub-sector therefore needs to increase efficiency for more customer convenience, reliability and accessibility with an aim of earning public confidence $[26,32]$. The ability to provide quality and inimitable services increases performance and is able to keep the Sacco competitive [38].

Performance measurement enables an evaluation and understanding of organizations' strategies and their effect on profitability. This allows the management to make informed decisions in regards to growth of the organization within a required time frame [6]. Performance of a firm is measured by the output or results against its intended outputs according to [31]. Saccos focus on non financial measures of performance that helps to increase operational efficiency. Operational efficiency on the other hand brings about; customer satisfaction, loyalty and brand image which when built over a period of time provide financial value to the Saccos [29]. 
BSC is a model and a measurement system that provides a balanced approach of organizational performance having all the four perspectives that are needed for increasing shareholder and customer value. The four perspectives are; customer perspective which examines how organizations align their strategies to satisfy the needs of their customers, the internal process perspective looks at the operational efficiency to deliver promised results to customers and shareholders, the learning and development examines employee motivation, skill and development and the financial perspective which is determined by the other three perspectives [22]. A satisfied customer is likely to buy more products, will not be price sensitive and will provide referrals through loyalty. In the cooperative sector, members who are satisfied with the services stay with their Saccos for many years till their retirement time thus more profitability.

The Altiman Z-Score model was used to determine performance of Kenya's Sacco corporate bankruptcy looking at profitability, liquidity and solvency [12]. The study found that there were Saccos that were healthy; some were deemed healthy while some were almost being shut down due to bankruptcy. The study recommended improvements in performance and noted that performance is a continuum as it changes over time.

Service differentiation is a strategy adopted by organizations with more focus on the content of the service delivered to the customers. This include the components of the service, the expertise and the delivery channel (Leverin, 2006) which creates a competitive advantage to organizations (as cited in UK Essays, 2016). Organizations that aim to remain competitive through service differentiation are concerned with their employee training to equip them with skills that can enable them deliver the best service that is inimitable and that which cannot be substituted. They also empower their customers through training making their customers to understand the business process thus be able to do self service at their convenient time. Good customer service augments Sacco products offerings to its members that go a long way in improving member satisfaction.

Saccos offer loans at low interest rates and encourage members to save by giving loans which are a multiplier of savings. The loans help in developing the members and in improving their welfare [8, 21]. Kenya's Saccos are among the best performing globally and number one in Africa [15, $25,41]$. The cooperative movement has contributed in the development and the realization of the Kenya's economic agenda through provision of financial services where people with low income, the unbanked, small and micro enterprises are able to access financial services to improve their economic status [11]. The cooperative movements are of two types; deposit taking and non deposit taking Saccos. There are 198 deposit taking Saccos in Kenya of which 41 of them are within Nairobi City County [32]. Deposits taking Saccos in Kenya are regulated by Sacco Societies Regulatory Authority (SASRA).

Saccos are working with the policy makers and other arms of the government to ensure that they bring their members on board through their service to the realization of the government's big four agenda. Though WOCCU noted the intensity of growth in the cooperative movement in Kenya and how it is leading both in Africa and globally, the external environment presents Saccos with challenges that have threatened their performance [41]. Cost of doing business and reduced saving power of the Saccos customers have reduced the revenue and access to cheap deposits that they use to give as loans to their members making them re-think their competitive strategy. The interest rate capping of the banking act passed in 2016, worked against cooperative sub sector as members moved away to seek alternative banking products thus reduced Sacco performance. Currently the subsector has witnessed many Saccos closing down due to poor performance.

Kageche observed that the Sacco sub-sector is shrinking and notes that banks will not be a formidable force in the near future [7]. A study by Darius noted how financial institutions are experiencing crisis where some are even collapsing thereby causing panic in the industry [24]. This has forced the financial institutions to change strategy to increase their performance. A study reported that there were Saccos that were almost going bankrupt and recommended improvement in performance [12]. Another study done reported how firms have achieved improvements in performance due to the unique strategy employed [39].

The study aimed at establishing how service differentiation affects the performance of deposit taking Saccos in Nairobi city county Kenya. Under this, the study looked at different ways of differentiating and improving services to customers and the effect the quality services had on the performance of the organization.

\section{Literature Review}

\subsection{Theoretical Review}

Porter developed generic strategy model with three different approaches; cost leadership, differentiation and cost focus [29]. The theory provides an explanation on how organizations can use different strategies to enable them gain competitive advantage over their peers thus increase their performance. Differentiation strategy on the other hand, provides competitive edge through unique company offers in various dimensions which customers appreciate through premium pricing, [30]. Hill states that mature industries which are undergoing technological changes differentiate making them become low cost [23]. This is achieved by strategic deployment of technology that sets Saccos above their competitors thereby distinguishing them. Saccos differentiate through their financial service offerings by designing new products and processes that increase member satisfaction thereby creating member loyalty. There are deposits taking Saccos that focus on specific membership to meet their needs according to their unique characteristics.

Saccos use differentiation but recommends constant review of products and services strategy and technology 
adoption in all operations to set them above their competitors [20]. A balanced score card model was developed and is used by businesses to monitor and measure their performance [9]. Successful implementation of BSC needs an assessment of mission and vision which is measured according to the determined indicators compared to the targeted performance. Many organizations control systems are built on short term measures that focus on financials without looking at their objectives in the long-term.

The study was guided by the BSC model by looking at the non financial metrics indicating organizational performance when service differentiation strategy is adopted.

\subsection{Empirical Literature Review}

A study on differentiation strategy, performance measurement systems and organizational performance relied on a sample of 200 working with senior managers as respondents [35]. Analysis was done through multiple regression and descriptive statistics. Correlation analysis was used to determine the existence of relationship between differentiation strategy and performance. The study found significant positive relationship between service differentiation and performance. The study had no true random sample.

The sample used was generated from big manufacturing companies that could not be generalized to the entire manufacturing industry. The study also used mailed questionnaire that reduced the response rate. This study consisted of all deposit taking Saccos thus offered broad representation fit for generalization. The study also used face to face self administered questionnaire to increase response rate and applied random sampling to increase reliability by reducing biasness. The study confirmed the previous study that there is a positive and significant relationship between service differentiation and organizational performance.

A study was done on competitive strategies and performance of public universities. It used descriptive design with a population of 162 heads of department [34]. The study used disproportionate stratified sampling technique to generate a sample consisting of 54 respondents. Purposive sampling was used to identify respondents. Questionnaire was used to collect data. Validity and reliability of the data was checked. Data analysis was done through descriptive, correlation and regression methods. The study results proved that service differentiation affected performance to a very great extent. The study focused on learning institutions. This study focused on financial institutions but found the same results where service differentiation was preferred to a large extent and had significant effect on organizational performance.

A study done on differentiation strategies used by classified hotels to increase their performance adopted descriptive design [16]. The study sample consisted of 44 hotels from Nairobi and Mombasa. The respondents were hotel general managers. Questionnaire was used where it was dropped to the participants and picked later at an agreed time. Descriptive analysis and inferential statistics were used. The study found that service quality and service delivery are widely practised as a service differentiation. The study also found that the hotels were carrying out periodic surveys to ensure that service standards were adhered to. The study was done in two Kenyan cities focusing on hotels. This study was done in one city and focused on financial industry where the study found that there was consistency in service delivery among deposit taking Saccos even though the respondents disagreed that the deposit taking Saccos used member feedback to improve service standards. The respondents also disagreed that there were quarterly surveys conducted to improve service differentiation.

A study was done on competitive advantage and service differentiation by manufacturing companies using a sample of 332 [4]. The study adopted cross-sectional survey with random sampling and face to face interviews. Validity and reliability was done. Descriptive, correlation and regression were used to analyse the data. The study found that service differentiation is a valuable resource that makes a firms' offering inimitable. It also increases payoff and strengthens the relationship between complexity of customer needs and organization's performance. The study environment was Europe targeting manufacturing industry. This study focused on Africa targeting financial industry but confirmed that service differentiation had significant effect on organizational performance.

\section{Conceptual Framework Differentiation Strategy}

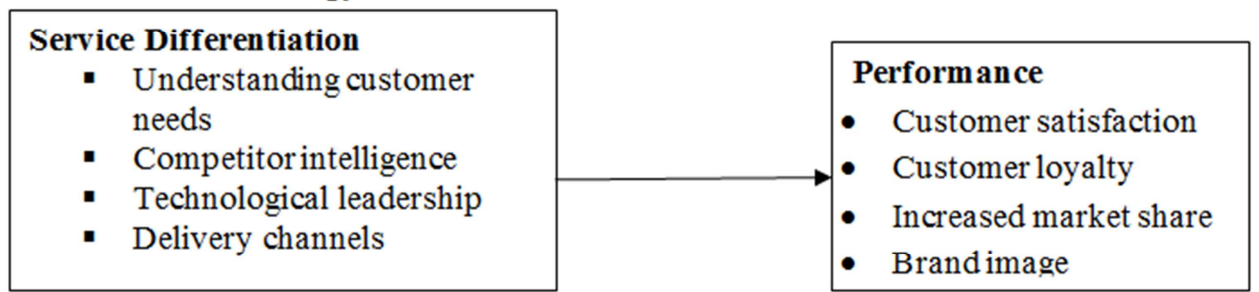

Independent variable

Dependent variable

Source: Researcher (2019).

Figure 1. Conceptual Framework 


\section{Research Methodology}

The study used descriptive research design to carry out the investigation. Descriptive study is defined as the process of finding out a certain phenomena, where to find it and the processes involved in finding the phenomenon [3]. Research design is defined as the road map or outline used to find solutions to research problem [17]. This is achieved by way of collecting data to determine the relationship between variables of the study. It is a recommended plan that incorporates all the different components of the research [19]. The methods is suitable for carrying out investigations, provide solutions to research problem and determining relationships among variables and hence was appropriate for looking into differentiation strategy and performance of deposit taking Saccos in Nairobi City County Kenya.

Population is defined as consisting of entire mass of observation where a sample is drawn [27]. The target population should have some observed similar behavior from where the study will derive the results [17]. The target population comprised of management employees of all 41 Deposit Taking Saccos registered and regulated by SASRA (2016) to operate in Nairobi City County. The study was conducted in Nairobi because Nairobi being the capital city of Kenya has diverse types of Saccos that are a fair representation of the Saccos in the entire nation.

From Table 1, the population consisted of $14 \%$ top level management, $36 \%$ middle management and 50\% low level management.

Table 1. Distribution of Target Population of the Study.

\begin{tabular}{lll}
\hline Cadres of Staff & Population & Percentage \\
\hline Top level management & 57 & 14 \\
Middle management & 151 & 36 \\
Low management & 202 & 50 \\
Total & 410 & 100 \\
\hline
\end{tabular}

Source: SASRA Report (2016).

Probability sampling design was used in the study for quantitative studies and a 30\% sample size which was 123 out of the total population of 410 [28, 14, 17]. Participants were gotten from the strata of the three levels of management using proportionate stratified sampling. A multiplier factor of 0.3 was used.

Proportionate stratified random sampling was used because the respondents in the departments were expected to have information and answers on the research questions that were being sought for. The study used management levels in the three levels because of the different and unique roles that each level of management plays in regards to differentiation strategy and performance of the deposit taking Saccos. This made it possible to handle all the issues raised in the questionnaires effectively. Systematic random sampling was then used to identify respondents within the respective DT Sacco offices. Table 2 indicated the sample size according to the different strata.

Table 2. Sample Size.

\begin{tabular}{lllll}
\hline Cadres of Staff & Population & Multiply factor 30\% & Sample size \\
\hline Top management & 57 & 0.3 & 17 & Percentage \\
Middle management & 151 & 0.3 & 45 & 14 \\
Low management & 202 & 0.3 & 61 & 36 \\
Total & 410 & & 50 & 123 \\
\hline
\end{tabular}

Source: Researcher (2019).

Table 2 shows a sample size of 123 where top level management were 17 which was $14 \%$ of the sample size, middle level management were 45 which was $36 \%$ of the sample and low level management were 61 which was $60 \%$ of the sample. This shows that the low level management was leading in sample size due to their number within the DT Saccos industry and hence had the highest input of $60 \%$ while top management had the smallest input of $14 \%$.

A questionnaire is defined as a research instrument designed for purposes of capturing information of interest to the study. The study used likert scale structured questionnaire to collect primary data [18]. A pilot study was done using 20 deposits taking Saccos outside Nairobi and this helped on improving the questionnaire further before it was issued to the respondents in Nairobi City County Kenya. The instrument was simple and easy to understand [13]. This was done in order to enhance its validity and accuracy of data to be collected for the study. Secondary data was generated from deposit taking Saccos literature materials, internet resources and other relevant materials related to the variables under study.
Expert opinion was sought from the project supervisor, library staff and other relevant individuals in line with the study. A letter of authorization to collect data was obtained from the University. Further approval from National Commission of Science, Technology and Innovation (NACOSTI) was obtained. Authorization from the respondent was sought through introduction letter. Data was then collected with assistant of three research assistants where the survey forms were dropped at the deposit taking Sacco offices and then picked later at an agreed time. To track all the survey forms given, a register of questionnaires and various deposit taking Saccos given was recorded for more follow-up at the time of collection. Validity and reliability help in improving the transparency and accuracy of the study. The study used both validity and reliability to support the study findings.

According to Yin (2003), validity is the degree to which a concept is accurately measured in a study. The researcher focused on face, content and constructs validity of the data collection instrument. Face validity was ensured through the input of experts in the thematic area of strategic management 
including the Supervisor and other academic staff in the school of business. Content and construct validity was achieved by undertaking an in depth and extensive review of relevant theoretical and empirical literature. A pilot study of the results was conducted to enhance both the validity and reliability of the expected outcomes from the questionnaires as shown in table 3 .

Reliability measures the internal consistency of the items in the research instrument (Borg and Gall, 2003; George and Mallery, 2003; Saunders, Lewis \& Thornhill, 2009). Furthermore, George and Mallery (2003) contend that Cronbach alpha index of at least 0.7 is a good threshold for establishing the reliability of research instrument. Statistical Package For Social Science was used to analyze the pilot data for reliability as shown in the table 3.

Table 3. Reliability and Validity Test Statistics.

\begin{tabular}{llll}
\hline Variable & $\begin{array}{l}\text { Chronbach's } \\
\text { alpha }\end{array}$ & $\begin{array}{l}\text { No. of } \\
\text { Items }\end{array}$ & Remarks \\
\hline Service differentiation & 0.839 & 9 & Reliable \\
DT Saccos Performance & 0.893 & 8 & Reliable \\
Overall Reliability & 0.866 & 17 & Reliable \\
\hline
\end{tabular}

Source: Survey Data (2019).

From Table 3, the findings indicated service differentiation $(\alpha=0.839)$, and DT Saccos performance $(\alpha=0.893)$. All the study variables were above 0.7 threshold recommended by Gliem and Gliem (2003) thus were reliable and fit for study analysis. The overall aggregate Chronbach's alpha was $(\alpha=0.866)$ which also indicated reliable data as it was above 0.7 thus the study concluded that the instrument was reliable.

The data analysis was done by use of a number of stages. The stages involved data processing to clean up the data. Data clean up to identify any errors was done and it involved editing of questionnaires for completeness and consistency, data coding and tabulation. Specific numerical values were assigned for to the responses for further analysis. Descriptive statistics was used to analyse demographic data using mean and standard deviation. It was then presented using charts, percentages and graphs. Inferential statistics involved the use of correlation where the study sought to find out the relationship between variables under study using Karl Pearson correlation [5]. Correlation is defined) as the extent to which a relationship conforms to a straight line which ranges from -1 to +1 where positive values indicate an increasing correlation, negative values provide a decreasing correlation while 0 means there is no correlation between variables [2]. The study used simple linear regression to explain cause and effect, where data was presented using tables [40]. The simple linear regression equation was as follows:

$$
\mathrm{Y}=\beta_{0}+\beta_{1} \mathrm{X}_{1}+\varepsilon
$$

Where; Y=Performance of Deposit Taking SACCOs in Nairobi City County Kenya

$\mathrm{X}_{1}=$ Service Differentiation

$\beta_{0}, \beta_{1}=$ Beta coefficients

$\varepsilon=$ Error term

\section{Research Findings and Discussion}

The study sampled and distributed 123 questionnaires to management staff of 23 Deposit Taking Saccos based in Nairobi County. Out of this, 78 questionnaires were duly filled thus giving a response rate of $63 \%$. Table 4 showed the study response rate.

Table 4. Response Rate.

\begin{tabular}{lll}
\hline Item & Frequency & Percent \\
\hline Returned questionnaires & 78 & 63 \\
Un returned questionnaires & 45 & 37 \\
Total & 123 & 100 \\
\hline
\end{tabular}

Source: Survey Data (2019).

The Results in Table 4 indicated that $63 \%$ response rate. Hardigan, Popovici and Carvajal (2016) noted that a response rate of $50 \%$ is adequate, $60 \%$ is good while $70 \%$ is very good (10). The study achieved a good response rate as it was above $60 \%$ which is considered good for study analysis. Further, study by Owino (2011) on competitive strategies adopted by savings and credit cooperative societies in Mombasa County also achieved $56 \%$ response rate. Thus this study therefore had a good response rate that was fit for analysis and reporting.

\subsection{Descriptive Statistics}

The study sought to describe the service differentiation strategy dimension and organizational performance using descriptive statistics. The study objective was to find out the effect of service differentiation strategy on performance of deposit taking Saccos in Nairobi City County, Kenya. The respondents were provided with 17 questions related to service differentiation strategy dimension and DT Saccos performance where they were to give their opinion on how they agreed with the statements. These were presented in a five point likert scale where they were to rate with choice ratings being; 5=very large extent, 4=large extent, $3=$ moderate extent, $2=$ little extent and $1=$ not at all. The mean and standard deviation were used in analysis.

Table 5. Service Differentiation.

\begin{tabular}{lll}
\hline Service Differentiation & Mean & Std. Deviation \\
\hline Our staffs provide consistent service to our members. & 4.38 & 0.59 \\
We have commission incentives to our members who give us referrals. & 4.35 & 0.63 \\
We offer differentiated mobile platform financial services to our members. & 4.33 & 0.60 \\
Our services provide unique experiences to our members. & 4.31 & 4.29 \\
There is promptness in handling members complaints & 4.28 \\
Our members are happy with our services. & 4.14 & 0.65 \\
We provide member portal services and other unique online services. & 0.70 \\
\hline
\end{tabular}




\begin{tabular}{lll}
\hline Service Differentiation & Mean & Std. Deviation \\
\hline We use member feedback to improve our services. & 4.09 & 0.90 \\
The Deposit Taking Saccos do quarterly survey to collect member feedback & 3.90 & 1.08 \\
Aggregate mean Score and Std. deviation & 4.23 & 0.74 \\
\hline
\end{tabular}

Source: Survey Data (2019).

Results on service differentiation strategy indicated that the respondents noted that the Deposit Taking Saccos staff provided consistent service to the members at 4.38 mean, gave commission incentives to the members who gave referrals at 4.35 . Offered differentiated mobile platform financial services at 4.33 , unique service experience to the members at 4.31 , promptness in handling complaints at 4.29 , members were happy with the services at 4.28 , provided member portal and other online unique services at 4.14 , used member feedback to improve services at 4.09 and does quarterly survey to collect member feedback at 3.90.

Overall, the aggregate mean score was 4.23 . This means many respondents were in agreement that service differentiation affects organizational performance to a large extent. The standard deviation of 0.74 indicated small variability with closeness to the mean which means that service differentiation is important and is applied in deposit taking Saccos to improve performance.

This finding is confirmed by a study that done noted that service differentiation was a valuable resource that improved a firms offering as the respondents indicated that staff provided consistent service with commission incentives that increased Deposit Taking Saccos offerings [4].

Further the researcher carried out analysis of the responses in relation to the organizations performance as shown in table 6 below.

Table 6. Organizational Performance.

\begin{tabular}{|c|c|c|}
\hline Organizational Performance & Mean & Std. Deviation \\
\hline Our members have given us new referrals due to their satisfaction with our products and services. & 4.35 & 0.56 \\
\hline Our Deposit Taking Sacco has improved in professionalism due to employee training. & 4.31 & 0.61 \\
\hline There is improvement in our Deposit Taking Sacco internal processes that has increased efficiency. & 4.28 & 0.66 \\
\hline There is employee growth due to career and education advancement. & 4.25 & 0.72 \\
\hline Members' loyalty has increased due to satisfaction with our products. & 4.20 & 0.75 \\
\hline Increased member education has increased satisfaction. & 4.20 & 0.75 \\
\hline Our brand recognition has improved in the Deposit Taking Sacco market. & 4.00 & 0.90 \\
\hline Aggregate mean Score and Std. deviation & 4.19 & 0.74 \\
\hline
\end{tabular}

Source: Survey Data (2019).

Results in Table 6 showed that the respondents noted that members had given their organization new referrals due to satisfaction at a mean of 4.35 , there was increased professionalism as a result of employee training at 4.31, improved internal processes leading to efficiency at 4.28 , employee growth due to career development and advancement at 4.25 , member loyalty increase due to satisfaction at 4.20 , increased member education leading to satisfaction at 4.20 , improved brand recognition at 4.00 and reduced employee turnover at 3.97. Overall the aggregate mean score for organizational performance was 4.19 with a standard deviation of 0.74 meaning that the respondents agreed to a large extent that there was increased performance. The standard deviation was also small an indication that data was close to the mean. The increase in performance was also confirmed study noting that brand value increased with efficient use of internal resources for competitive advantage [36].

\subsection{Inferential Statistics}

\subsubsection{Correlation Analysis}

The study sought to determine the relationship between differentiation strategy and Deposit Taking Saccos performance using Karl Pearson Correlation. Correlation is defined as the assessment of the direction and strength of the relationship between variables where values that are close to +1 have high positive correlation, those that are equal to 0 have no correlation while those that are close to -1 have high negative correlation $[5,1]$. The importance of correlation can also be judged based on the significance level where observed data provides evidence to reject the null hypothesis that the population parameter is equal to zero thus arriving at a conclusion that population correlation is not equal to zero [37].

Table 7. Correlation Analysis.

\begin{tabular}{lllll}
\hline & Performance & Product & Market & Service \\
\hline Performance Pearson Correlation & 1 & $.585^{* *}$ & $.464^{* *}$ & $.635^{* *}$ \\
Sig (2-tailed) & & 0.000 & 0.000 & 0.000 \\
$\mathrm{n}$ & 78 & 78 & 78 & 78 \\
Service Pearson Correlation & & & 0.000 & 78 \\
Sig (2-tailed) & & & $.639^{* *}$ & \\
$\mathrm{n}$ & & & \\
\hline
\end{tabular}

**Correlation is significant at the 0.01 level (2-tailed).

Source: Survey Data (2019). 
Results in Table 7 showed that the study found service differentiation had $(\mathrm{r}=0.635$, $\mathrm{p}$-value 0.000$)$. This indicated positive correlation which means that as service differentiation strategy increased, Deposit Taking Saccos performance increased.

\subsubsection{Simple Linear Regression Analysis}

The research conducted simple linear regression analysis with an intention of establishing the statistical equation that can be used to determine the effect of service differentiation on performance of Deposit taking Saccos in Nairobi City County Kenya. This was realized by regressing service differentiation on Sacco performance. The results of the simple regression are as shown in tables 8,9 and 10 respectively.

Table 8. Output of Model Summary.

\begin{tabular}{lllll}
\hline Model 1 & R & R Square & $\begin{array}{l}\text { Adjusted R } \\
\text { Square }\end{array}$ & $\begin{array}{l}\text { Std. Error of the } \\
\text { Estimate }\end{array}$ \\
\hline 1 & $.759^{\mathrm{a}}$ & .576 & .553 & .42588 \\
\hline
\end{tabular}

a. Dependent Variable: Firm Performance.

b. Predictor: Service Differentiation.

Source: Survey Data (2019).

From Table $8, \mathrm{R}=0.759$ is a correlation coefficient indicating the strength of the relationship between service differentiation strategy and Deposit Taking Saccos performance. Adjusted $\mathrm{R}$ square of 0.553 indicated that $55.3 \%$ of differentiation strategy accounted for Deposit
Taking Saccos performance. The other $44.7 \%$ can be explained by other factors other than those covered by the study objective hence there is need for future studies to discover the other factors that cause organizational performance.

Analysis of variance (ANOVA) sought to provide a statistical test for the model fitness.

The output of this test presented in table 9 .

Table 9. Results of Analysis of Variance (ANOVA).

\begin{tabular}{llllll}
\hline Model & $\begin{array}{l}\text { Sum of } \\
\text { Squares }\end{array}$ & Df & $\begin{array}{l}\text { Mean } \\
\text { Square }\end{array}$ & F & Sig. \\
\hline Regression & 18.023 & 4 & 4.506 & 24.843 & $.000^{\mathrm{b}}$ \\
Residual & 13.240 & 73 & .181 & & \\
Total & 31.264 & 77 & & & \\
\hline
\end{tabular}

a. Dependent Variable: Firm Performance.

b. Predictor: Service Differentiation.

Source: Survey Data (2019).

Results in Table 9 indicated that the study found that differentiation strategy is significantly related with Deposit Taking Saccos performance. This is evident from the $(p=0.000)$ which was as per the required level of $p$ value $=0.05$. The study confirmed findings that unique differentiation strategy employed by organizations significantly affected performance [39].

The output of the regression coefficients of service differentiation are presented in table 10 .

Table 10. Regression Coefficient.

\begin{tabular}{lllll}
\hline Model & \multicolumn{2}{c}{ Unstandardized Coefficients } & Standardized Coefficients & Sig. \\
\hline & B & Std. Error & Beta & \\
\hline Constant & -.287 & .465 & & -.616 \\
Service Differentiation & .348 & .119 & .302 & .540 \\
\hline
\end{tabular}

Source: Survey Data (2019).

From Table 10, when all factors are held constant, performance would reduce by $(-0.287)$ while one unit increase in service differentiation would lead to 0.348 increase in organizational performance. Regression model that was used in the analysis was thus:

\section{Performance $=-287+0.348$ Service differentiation}

The researcher aimed to determine the effect of service differentiation on performance of deposit taking Saccos. Service differentiation $(\beta=0.348, p$ value $=0.005<0.05)$. The findings indicated in Table 10 prove that an increase in service differentiation resulted to 0.348 increase in organizational performance. Further, it was also revealed that service differentiation had statistical significant effect on organizational performance as the $\mathrm{p}$ value was below 0.05 . The study thus concluded that service differentiation had positive and significant effect on performance of DT Saccos in Nairobi City County. There is a positive significant relationship between service differentiation and organization performance [35]. Service differentiation is a valuable resource that makes a firm's offering inimitable which is one of the attributes of an organization's resource requirements that can be used to increase competitive advantage [4]. Porter's generic strategy of differentiation enables organizations to be unique thus more competitive advantage for increased organizational performance [29].

\section{Summary}

The study had a good response rate that was considered fit for analysis and reporting. Many of the management staff was between the ages of 30-40 meaning that they were mature to provide reliable answers. They also had experience as all of them had worked in their respective Deposit taking Saccos for more than one year giving them opportunity to acquire experience needed to make strategic decisions. The respondents' majority had attained a minimum of bachelor level that indicated acquisition of skills to lead in various strategic decisions and a good understanding of differentiation strategy as a tool for organizational 
performance improvement. The male gender were the majority management staff of Deposit Taking Saccos indicating that male have taken the lead in Saccos strategic decision making to improve organizational performance.

The study's objective was to determine the effect of service differentiation on organizational performance among Deposit Taking Saccos in Nairobi City County, Kenya. From the analysis of the descriptive, the study proved that the Deposit Taking Saccos staff provided consistent service to the members, gave commission incentives to the members who gave referrals, offered differentiated mobile platform financial services, gave unique service experience to the members, were prompt in handling customer's complaints and members were happy with the services. All these led to increased business performance.

However, the respondents disagreed that the Deposit Taking Saccos were using member's feedback and quarterly surveys to improve service. The respondents therefore agreed to a large extent that service differentiation affects organizational performance. The study also found that $(\beta=0.348, p$ value $=0.005<0.05)$ service differentiation was positively and significantly affecting organizational performance therefore meeting the objectives of the study.

\section{Conclusion, Recommendation for Policy, Practice and Contribution to the Body of Knowledge}

The researcher sought to determine the effect of service differentiation and organizational performance of Deposit Taking Saccos in Nairobi County, Kenya. The study concluded that service differentiation had positive and significant effect on performance of deposit taking Saccos in Nairobi City County Kenya.

Policy makers in deposit taking Saccos in Nairobi City County Kenya should use the recommendations to improve on performance. The recommendations in this study have also added to the body of knowledge. The academicians now have the research materials where to build future cases and findings of their research.

The study noted a problem with feedback insight that the Deposit Taking Saccos receive as it was not being used to increase service differentiation. The study recommended to the management to come up with standard procedures and guidelines that will be used to reinforce the effective implementation of feedback received from customers to spearhead service improvement. The management should automate their customer touch points to enable generation of real time data with analytics for timely decision making.

\section{Recommendations for Further Research}

The study focused on differentiation strategy where specific objective was service differentiation. The study recommends future research in other Deposit Taking Saccos strategies to understand how they affect performance. Further, other differentiation strategies can be explored to determine the effect on organizational performance. The study location was based in Nairobi City County with a sample size of 123. Future studies can be done in other locations with a bigger sample to understand Deposit Taking Saccos organizational performance.

\section{References}

[1] Beaumont, R. (2012). An introduction to statistical correlations.

$\mathrm{http} / / /$ www.robin.beaumont.co.uk/virtual/classroom/stats/cour sel.html.

[2] Buxton, R. (2008). Statistics: Correlation mathematics. Learning Support Centre.

[3] Cooper, D. and Schindler, P. (2015). Business Research Methods (10 $0^{\text {th }}$ Ed.). Boston: McGraw-Hill International Edition.

[4] Gabauer, H., Gustafsson, A. \& Witell, L. (2011). Competitive advantage through service differentiation by manufacturing companies. Journal of Business Research, 64 (12), 1270-1280. http://dx.doi.org/10.1016/j.jbusres.2011.01.015.

[5] Heron, E. (2009). Correlation and regression.

[6] Jenatabadi, H., S. (2015). An overview of organizational performance index: Definitions and measurements. Research Gate, Doi: 10.13140/RG.2.1.4298.3849 Financial Sector Regulators forum (2017). The Kenya financial sector stability report

https://www.centralbank.go.ke/uploads/financial_sector_stabil ity/1795707109_Kenya\%20Financial\%20Stability\%20Report \%202016\%20final\%20version.pdf.

[7] Kageche, J. (2016). Why strategic selling within financial sector is on shifting sands. Biashara Leo, 096, 36-37.

[8] Kamonjo, K. L. (2014). Corporate governance practice and its effect on financial Performance in SACCOs (A case study of urban SACCOs in Kirinyaga County-Kenya). Nairobi: Kenyatta University.

[9] Kaplan, R. \& Norton D., P. (n. d). Using the balance score card as a strategic management system. Harvard Business Review. www.hbrreprints.org.

[10] Kavulya, P., W. (2018). Effect of deposit mobilization strategies on the performance of deposit taking savings and credit cooperative societies in Kenya. Jomo Kenyatta University of Agriculture and Technology.

[11] Kimata, O., N. (2013). Effects of financial innovation on the financial performance of deposit taking savings and credit cooperative societies in Nairobi County. University of Nairobi.

[12] Kivuvo, R., M. \& Olweny, T. (2014). Financial performance analysis of Kenya's Sacco sector using the Atiman Z Score model of corporate bankruptcy. International Journal of Business and Social Science, 5 (9), 1.

[13] Kothari, C., R. (2004). Research methodology: Methods and techniques. $2^{\text {nd }}$ ed. New Delhi. New Age International. 
[14] Latham, B. (2007). Sampling: What is it? Quantitative Research Methods. Spring.

[15] Maina, E., N. \& Waithaka, P. (2018). Differentiation strategy and performance of deposit taking Saccos in Muranga County. The Strategic Journal of Business and Change Management, 5 (3), 34-43.

[16] Matanda, M., C. (2005). Differentiation strategies used by classified hotels in major cities in Kenya. University of Nairobi.

[17] Mugenda, M. O. and Mugenda, (2003); Research Methodology, Acts Press, Nairobi.

[18] Nayak, J., K. \& Singh, P. (2015). Fundamentals of Research Methodology: Problems and Prospects. New Delhi. India. SSDN.

[19] Ngatia, E., W., Muya, J. \& Ngacho, C. (2018). Relationship between competitive strategies and performance of savings and credit cooperative societies: Case of Mwalimu National Sacco in Kenya. International Journal of Social Sciences and Information Technology, 6 (10).

[20] Ngugi, J., N. (2017). Effect of competitive strategies on sustainable competitive advantage of savings and credit cooperative societies in Mombasa County. Strategic Journal of Business and Change Management, 4 (2). strategicjournals.com/index.php/journal/article/view/429.

[21] Ngure, F., K., Maina, K., E. \& Kariuki, S. (2017). Product innovations and financial performance of savings and credit cooperative societies in Kirinyaga County, Kenya. International Academic Journal of Human Resource and Business Administration. http://www.iajournals.org/articles/iajurbav213166178.pdf.

[22] Niven, P., R. (2006). Balance score card: Step by step maximising performance and maintaining results. $2^{\text {nd }}$ ed. Wiley.

[23] Ogot, M., M. (2014). Generic competitive business strategy and performance of micro and small enterprises in Nairobi: An empirical validation of the sme typology. University of Nairobi.

[24] Ombati, A., O. \& Muturi, W. (2017). Effects of competitive strategy on performance of microfinance institutions in Kisii County. International Journal of Economics, Commerce and Management, 5 (4).

[25] Ondigo, H. \& Ongaki, K., B. (2016). Determinants of financial performance of deposit taking microfinance institutions and cooperative societies that have front office service activities registered by SASRA. International Journal of Finance and Accounting, 1 (3), 118-138.

[26] Ozturk, e. \& Coskin, A. (2014). A Strategic approach to performance management in banks: The Balance score card. Accounting and Finance Research, 3 (3). Doi: 10.5430/afr.v3n3p151.

[27] Pandey, P. \& Pandey, M., M. (2015). Research Methodology: Tools and techniques. Romania: Bridge Centre.

[28] Phrasisombath, K. (March, 2009). Sample size \& sampling methods. Vientiane: University of Health Sciences.

[29] Porter, M., E. (1980). Competitive strategy: Techniques for analysing industries and competitors. USA. The Free Press.

[30] Putra, Y., S. \& Suhato, S. (2018). Analysis of differentiation strategy to create competitive advantage in facing global markets. The First International Research Conference in Economics and Business.

[31] Richard, P. (2009). Measuring Organizational Performance: Towards Methodological Best Practice. Journal of Management. Vol. 35. Pp 718.

[32] SASRA (2017). Deposit taking Saccos licensed by the Sacco Societies Regulatory Authority.

[33] Senbet, L., W \& Otchere, I. (2005). Financial sector reforms in Africa: Perspectives on issues and policies. Research Gate.https://www.researchgate.net/publication/237443631.

[34] Sifuna, I., N. (2014). Effect of competitive strategies on performance of pubic universities in Kenya. Kenyatta University.

[35] Spencer, S., Y., Joiner, T., A. \& Salmon, S. (2007). Differentiation strategy, performance measurement systems and organizational performance: Evidence from Australia. International Journal of Business, 14 (1).

[36] Suntanto, E., M. \& Sudarsono, D. (2018). Empirical analysis of firm resources in the banking industry in Indonesia: A resource based view. International Journal of Business and Society, 19 (3).

[37] Taylor, R. (1990). Interpretation of the correlation coefficient: A basic review. JDMS, 1, 35-39.

[38] Yuliansyah, Y., Rammal, H., G. \& Rose, E. (2016). Business strategy and performance in Indonesia' service sector. journal of Asian business studies, 10 (2), 164-182.

[39] Wachira, K., J. (2013). Competitive strategy and performance of financial sector companies listed in the Nairobi securities exchange. University of Nairobi.

[40] Walliman, N. (2011). Research methods: The basics. London. Uk. Routledge.

[41] World Council of Credit Unions (February, 2013). Member statistics. http://www. woccu.org/about/intlcusystem. 